Abstracta Iranica Iranica

Revue bibliographique pour le domaine irano-aryen

Volume 27 | 2006

Comptes rendus des publications de 2004

\title{
The Unthinkable Revolution in Iran. Harvard University Press, 2004.
}

\section{Anicée Van Engeland-Nourai}

\section{(2) OpenEdition}

1 Journals

\section{Édition électronique}

URL : http://journals.openedition.org/abstractairanica/6576

DOI : 10.4000/abstractairanica.6576

ISSN : 1961-960X

Éditeur :

CNRS (UMR 7528 Mondes iraniens et indiens), Éditions de l'IFRI

\section{Édition imprimée}

Date de publication : 15 mai 2006

ISSN : 0240-8910

\section{Référence électronique}

Anicée Van Engeland-Nourai, «The Unthinkable Revolution in Iran. Harvard University Press, 2004. », Abstracta Iranica [En ligne], Volume 27 | 2006, document 341, mis en ligne le 02 janvier 2007, consulté le 25 septembre 2020. URL : http://journals.openedition.org/abstractairanica/6576 ; DOI : https:// doi.org/10.4000/abstractairanica.6576

Ce document a été généré automatiquement le 25 septembre 2020.

Tous droits réservés 


\title{
The Unthinkable Revolution in Iran. Harvard University Press, 2004.
}

\author{
Anicée Van Engeland-Nourai
}

1 La révolution iranienne était-elle prévisible? Selon l'A., la surprise des autorités américaines à la révolution de 1979 n'est pas un échec car toutes les révolutions ne peuvent pas être prévisibles. La révolution aurait été inattendue tout comme l'avènement de l'Ayatollah Khomeiny au pouvoir.

2 Le sociologue Kurzman analyse cinq types d'explications des causes de la révolution iranienne : arguments politique, organisationnel, culturel, économique et militaire, et les écarte tous : pour chaque paradigme il démontre qu'il n'était pas possible de prévoir la révolution iranienne de 1979 et propose ce qu'il appelle une « contre explication » : il perçoit la révolution comme un élément instable, confus et inattendu que nul ne peut prédire. Son approche déconstructiviste va à l'encontre des analyses rétroactives qui essayent d'expliquer les causes de la révolution de 1979.

3 La méthodologie de l'ouvrage est innovante car l'A. a procédé à des entretiens avec les acteurs de la révolution, comme les étudiants et les commerçants, et relate également des anecdotes. Il donne ainsi une voix populaire à la révolution.

INDEX

Thèmes : 12.1. Iran 


\section{AUTEURS}

ANICÉE VAN ENGELAND-NOURAI

Paris 